\title{
Analysis of the policy background of transport related use of renewable energy
}

\section{T. PRINCZ-JAKOVICS}

Budapest University of Technology and Economics, Faculty of Economic and Social Sciences, Department of Environmental Economics, tprincz@eik.bme.hu

Abstract. The EU energy policy prioritizes the following principles: sustainability, competitiveness and security of supply and addresses the reduction of greenhouse gas emissions as a priority. The related EU policy (including the White Paper on Transport) outlines these principles, identifies goals and opportunities for action. At company level methodological guidelines and standard procedures can be used to assess the carbon footprint of the organization, to generate efficiency goals and to prepare action plans. In the Hungarian policy framework, a comprehensive National Sustainable Development Framework Strategy defines the basic principles for the analysis of the sectorspecific or regional strategies. Sustainable Energy Action and Climate Plans (SECAPs) integrate energy and climate issues and include interventions and improvements for the better use of renewable energy sources in transport at municipal level. As a summary it can be stated that exploration of the policy background would needed to influence the use of renewable energy sources for transport and definition of the development goals can help economic organizations to transform their mobility patterns and reduce related carbon footprint.

\section{Introduction}

From the economic sectors, transport is the priority energy user, therefore higher share of renewable energy sources should be achieved by prudent regulatory practices both at European and national level. The Hungarian and EU policies on new generation fuels provide goals for promotion of trends in a favourable direction and adapt support policies in the changing market conditions. The use of energy in transport increases year by year, however reduction of external costs requires improvements in the efficiency of the regulations. The purpose of this article is to review policy documents and ideas affecting the market for renewable energy sources in transport as a common area of energy and mobility management.

\section{Background of the analysis}

International scientific background is diverse and has changed significantly over the last decade. The earlier perceived, perhaps excessive, optimism was replaced by a more realistic approach. Due to the importance of energy use in transport, the topic of renewable energy sources can be considered as a "hot topic", but at the same time there was not special attention on the environmental characteristics and on the market-driving interests. 


\subsection{Environmental economics background}

Transport contributes significantly to the emissions and thus causes social damage. Externality can be interpreted as an external economic impact; however in the absence of available data estimation of these impacts is particularly difficult. Reliable comparative detailed analysis of the externalities of European countries is therefore relatively rare. According to CE Delft's analysis (CE Delft, 2011), the external cost of the EU-27 (including Switzerland and Norway) is 500 billion EUR per year (at the level of year 2008), which corresponds to 4\% of GDP. This is further compounded by congestion costs: $146-$ 243 billion EUR / year (about 1-2\% of GDP). The distribution of the externalities can be described by the following ratio: passenger transport: $77 \%$, freight transport: $23 \%$. Consequently, the use of renewable energy can make a significant contribution to the reduction of external costs.

\subsection{Market features}

Changes in the share of the use of renewable energy sources over a given time period can be a good indicator. According to the table published by the Hungarian Energy and Utilities Agency (MEKH), there has been no significant shift in the recent years, a slow increase is observed in the share of the use of energy from renewable energy sources in transport.

\begin{tabular}{|l|l|l|l|l|l|l|l|}
\hline Name & $\mathbf{2 0 1 0}$ & $\mathbf{2 0 1 1}$ & $\mathbf{2 0 1 2}$ & $\mathbf{2 0 1 3}$ & $\mathbf{2 0 1 4}$ & $\mathbf{2 0 1 5}$ & $\mathbf{2 0 1 6}$ \\
\hline $\begin{array}{l}\text { The proportion of electricity produced } \\
\text { from renewable energy sources in gross } \\
\text { final electricity consumption }\end{array}$ & 7.1 & 6.4 & 6.1 & 6.6 & 7.3 & 7.3 & 7.2 \\
\hline $\begin{array}{l}\text { The share of gross consumption of heating } \\
\text { energy from renewable energy sources for } \\
\text { heating and cooling in heating and cooling }\end{array}$ & 18.1 & 20.0 & 23.3 & 23.7 & 21.2 & 21.2 & 20.8 \\
\hline $\begin{array}{l}\text { The share of the use of energy from } \\
\text { renewable sources in transport }\end{array}$ & 6.0 & 6.0 & 5.9 & 6.2 & 6.9 & 7.0 & 7.4 \\
\hline $\begin{array}{l}\text { The share of the use of energy from } \\
\text { renewable energy sources in gross final } \\
\text { energy consumption }\end{array}$ & $\mathbf{1 2 . 7}$ & $\mathbf{1 4 . 0}$ & $\mathbf{1 5 . 5}$ & $\mathbf{1 6 . 2}$ & $\mathbf{1 4 . 6}$ & $\mathbf{1 4 . 4}$ & $\mathbf{1 4 . 2}$ \\
\hline
\end{tabular}

Table 1. The share of the use of renewable energy sources in gross final energy consumption [Based on: MEKH ${ }^{1}$ ]

The major proportion of the total renewable energy (86 TJ is allocated for domestic use (81 TJ) and only $39 \%$ of the produced biofuels (5 TJ) are exported. Domestic renewable energy production of biomass is $87 \%$ / 75 TJ, including 68\% / 59 TJ solid biomass, 4\% / 3 TJ biogas, 15\% / 13 TJ biofuels (Popp-Bai, 2018).

Analysis of the economic trends is also needed to compare the dynamics of change in energy use. This is supported by the indicator of the Hungarian Central Statistical Office (KSH, 2016), which shows that the energy consumption of transport (see chart below) did not exceed the value of economic growth after the peak of year 2009. The increase in energy consumption in the transport sector has therefore been lower than GDP growth.

\footnotetext{
${ }^{1}$ http://www.mekh.hu/eves-adatok
} 


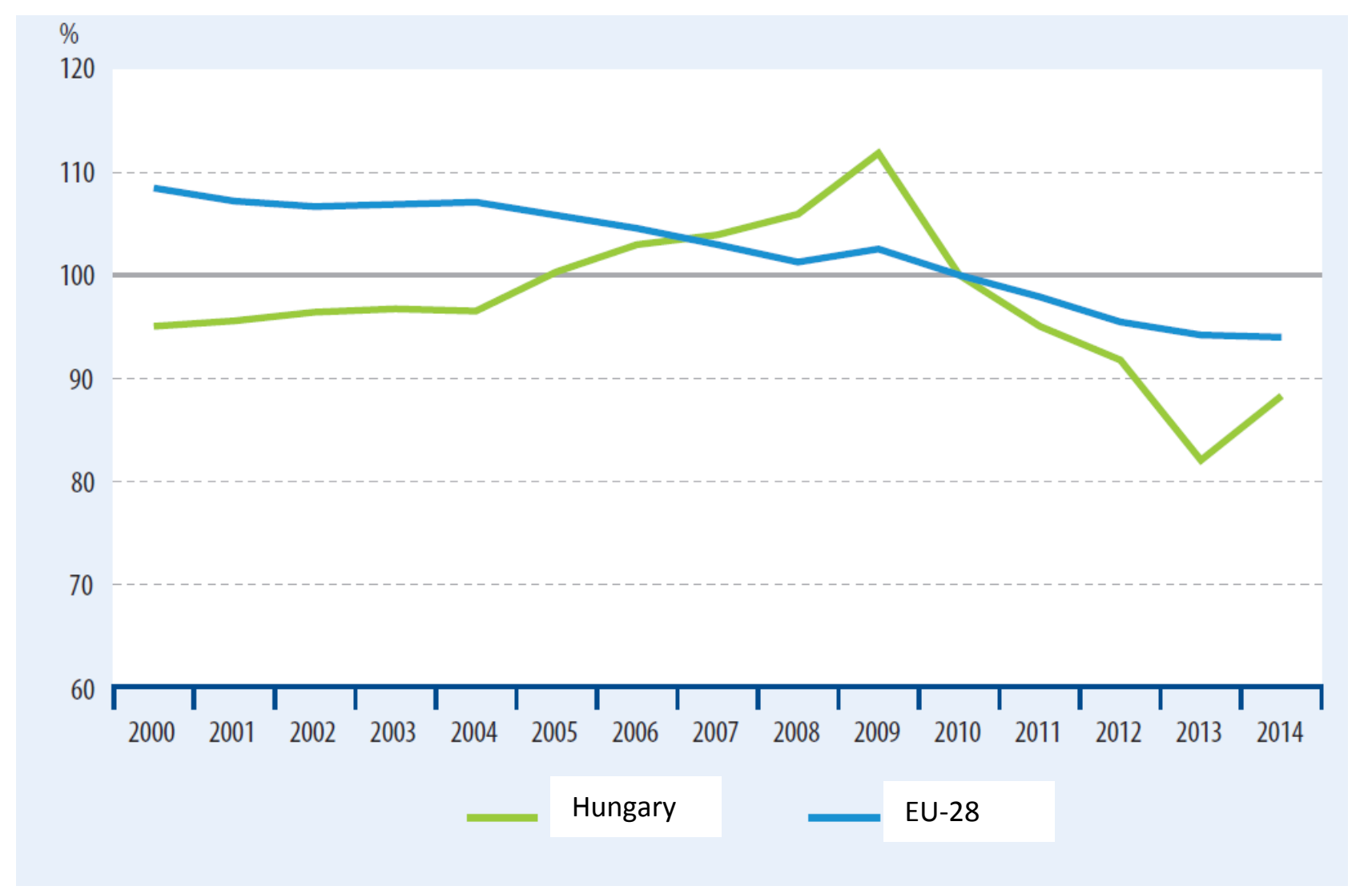

Figure 1. Energy use of transport in proportion to GDP [Source: KSH (2017)2]

Although transport has become cleaner recently, 96\% of the energy use is still derived from fossil fuels. That is why the major goal is to improve the use of renewable energy. Despite their favorable characteristics, domestic use of biofuels is mostly linked to compulsory mixing in fossil fuels, so it would be advisable to promote $\mathrm{R} \& \mathrm{D}$, further increase the rate of compulsory mixing currently in force, and encourage bio methane use. Biofuels produced from food crops, however, affect the development of land use and hence food supply and this must also be taken into account (Popp-Bai, 2018).

\section{Relevant policy documents}

\subsection{EU policy documents}

\subsubsection{White paper on Transport}

The White Paper on Transport published in 2011: "Roadmap for a Single European Transport Area Towards a Competitive and Resourceful Transport System" (COM (2011) 144). The document concludes that the efficiency of transport systems contributes to the competitiveness of the European companies, so its development is indispensable. One of the major challenges is to reduce greenhouse gas emissions from the transport movements. Overall, EU member states will have to reduce emissions

${ }^{2}$ www.ksh.hu/docs/hun/xftp/idoszaki/fenntartfejl/fenntartfejl16.pdf 
by $80-95 \%$ by 2050 related to the level in year $1990,60 \%$ of this decline should be provided by the transport sector.

The objective of achieving environment-friendly transport: development and application of new and sustainable fuels and propulsion systems. The aim was to reduce the number of cars operating in urban traffic by 2030, and their total withdrawal in the big cities by 2050 .

\subsubsection{SECAPS}

Sustainable Energy Action and Climate Plans (SECAPs) combine energy and climate issues, including interventions and development ideas for the use of renewable energy sources in transport at the municipal level. The SECAPs quantify the most important indicators and identify interventions and development modes that help achieve the goals.

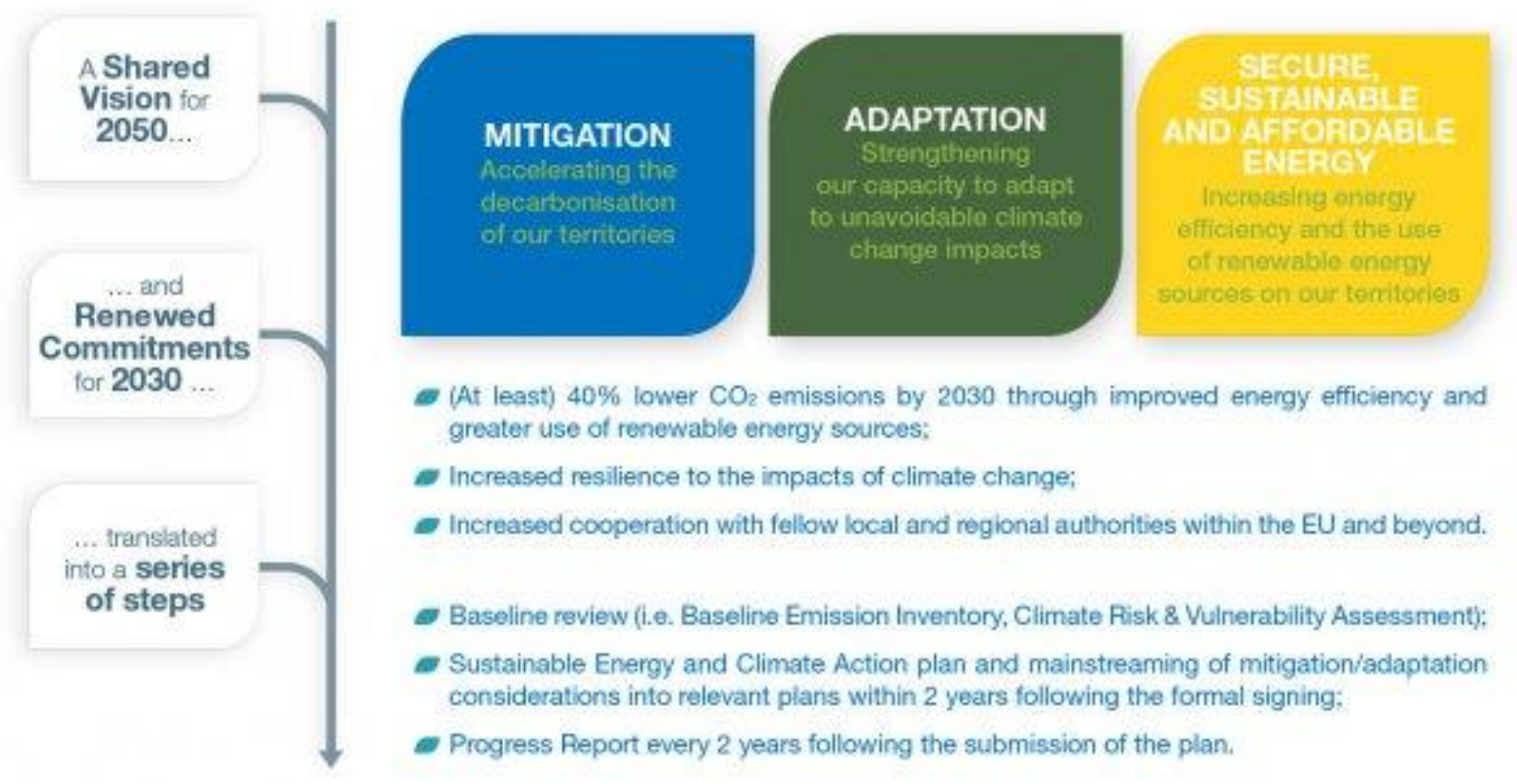

Towards more sustainable, attractive, fiveable, resilient and energy efficient local authorities

Figure 2. New 2030 Framework and Integration of Adaptation for SECAPS

[Source: http://www.covenantofmayors.eu]

\subsection{National policy documents}

\subsubsection{National Sustainable Development Framework Strategy}

The National Sustainable Developmental Framework Strategy (NFFT, 2013), adopted by the National Assembly in 2013, aims to bring the nation's long-term orientation to our individual and community actions. The framework strategy defines sustainability as a sustainable development policy that assures long-term resource management and allocates four resources: human, social, natural and economic resources. According to the Framework Strategy, the use and shift to renewable resources 
entails additional costs for economic operators, and therefore it is justified to support investments aimed at more efficient replacement of fossil resources. It is also necessary to support technologies using renewable resources and to increase related investments.

\subsubsection{National Energy and Transport Strategy}

The National Energy Strategy 2030 (NFM, 2012) focuses on prioritizing the achievement of EU objectives (see previous subsection) to increase the share of low $\mathrm{CO}_{2}$-emitting modes of transport. However, increasing use of bio-ethanol, biodiesel and biogas as renewable energy sources would help reduce $\mathrm{CO}_{2}$ emissions from transport.

The Renewable Energy Utilization Action Plan (NFM, 2010) has a higher proportion than the EU level, $14.65 \%$ of the renewals. Although the share of renewables in the energy supply of Hungary is growing, there is a need for further efforts to maintain a favorable trend and increase the share of renewable energy sources in total gross final energy consumption. This requires a regulatory and licensing system to promote the use of renewable energy sources.

The National Infrastructure Development Strategy /NKS/ (Strategy Consortium (2013)) does not include ideas for the use of renewable energy sources. Thus, the development and modification of the infrastructure has an impact on the mileage of the vehicles and the modal split of traffic performances. The NKS target system presents the following goals among the social objectives: "Reduction of negative impacts on the environment and the enforcement of climate protection considerations: This is partly intended to improve the environment and the condition of the environment. Another major area of concern is sustainable management of natural resources. It is also important to reduce the use of non-renewable energy and raw materials."

\section{Summary}

After the analysis of the policy background the following statements can be made:

- exploring the policy context that influences the use of renewable energy sources for transport is essential,

- improved efficiency of regulations can reduce external effects (eg. climate effect),

- transport sector has significant greenhouse gas emissions and a high carbon footprint value, the reduction of emissions is a long-term task according to both national and international expectations,

- definition and elaboration of action plans can help organizations to develop or transform their mobility and transport activities, and reduce their carbon footprints.

\section{References}

[1] CE Delft (2011) External Costs in Europe.

[2] COM (2011) 144, White Paper on Transport "Roadmap for a Single European Transport Area Towards a Competitive and Resourceful Transport System" 
[3] Hungarian Central Statistical Office, KSH (2016) Indicators of the sustainable development in Hungary, 2016 „A fenntartható fejlődés indikátorai Magyarországon, 2016”

[4] Hungarian Energy and Utilities Agency, MEKH (2017) Share of renewable energy sources in 20042015, "Megújuló energiaforrások felhasználásának részaránya 2004-2015" http://www.mekh.hu/eves-adatok

[5] Ministry of National Development, NFM (2010) The Renewable Energy Utilization Action Plan of Hungary, "Magyarország Megújuló Energia Hasznosítási Cselekvési Terve"

[6] Ministry of National Development, NFM (2012) National Energy Strategy 2030 "Nemzeti Energiastratégia 2030"

[7] NFFT (2013) National Sustainable Developmental Framework Strategy "Nemzeti Fenntartható Fejlődési Keretstratégia"

[8] J. Popp - A. Bai (2018) Renewable energy sources, in particular biofuel production: international outlook, "Megújuló energiaforrások, különös tekintettel a bioüzemanyag-gyártásra: nemzetközi kitekintés". Hungarian Science, Magyar Tudomány. 179 (8) pp. 1197-1207.

[9] Strategy Consortium, Stratégia Konzorcium (2013) National Infrastructure Development Strategy, "Nemzeti Közlekedési Stratégia", Budapest.

\section{Acknowledgement}

The research reported in this paper was supported by the Higher Education Excellence Program of the Ministry of Human Capacities in the frame of the Water sciences \& Disaster Prevention research area of BME (BME FIKP-BIO). 